\title{
An approach to unraveling the coexistence of snappers (Lutjanidae) using otolith morphology
}

\author{
Zahra Sadighzadeh ${ }^{1}$, Jose Luís Otero-Ferrer ${ }^{2}$, Antoni Lombarte ${ }^{3}$, Mohammad R. Fatemi ${ }^{1}$, \\ Víctor Manuel Tuset ${ }^{3}$ \\ ${ }^{1}$ Marine Biology Department, Graduate school of Marine Science and Technology, Science and Research Branch, \\ Islamic Azad University, Tehran, Iran. E-mail: zahrasadighzadeh@yahoo.com \\ ${ }^{2}$ Universidade de Vigo, Departamento de Ecología y Biología Animal, Vigo, Galicia, Spain. \\ ${ }^{3}$ Institut de Ciéncies del Mar (CSIC), Passeig Marítim 37-49, 08003, Barcelona, Catalonia, Spain.
}

\begin{abstract}
Summary: The sagittae otolith morphology of marine fishes has been used in many ecomorphological studies to explain certain ecological adaptations of species to habitat. Our study compares the sagittal otolith shapes of ten species of snappers (Family Lutjanidae) inhabiting the Persian Gulf. We used a morphometric analysis of the otolith measurements (length, height, perimeter, area and weight) and of the ratio between the area of the sulcus acusticus and the area of the otolith (S:O). The otolith contour was also analysed using wavelets as a mathematical descriptor. Morphological variations in the otoliths were associated with the morphology and external colouration of snappers as well as ecological traits. An analysis of the interspecific S:O ratio suggested that the highest ratios occurred in snappers inhabiting shallower waters. A categorical multivariate analysis, including morphological, ecological and otolith size factors, showed that the species adapted to dim light conditions had a greater otolith perimeter. An analysis of variance of the otolith contour revealed zones with a higher interspecific variability, although only the antero-dorsal zone showed differing patterns. Although the otolith patterns appear to have a phylogenetic component, they might also be related to diel activity rhythms or to the light conditions in the habitat. The results of the study showed that variation in otolith morphology can be used to explain the coexistence of sympatric species.
\end{abstract}

Keywords: otolith; morphology; biodiversity; functional ecology; snappers; Lutjanidae.

Una aproximación a la comprensión de la coexistencia de pargos (Lutjanidae) a partir de la morfología del otolito

Resumen: La morfología del otolito sagitta de peces marinos se ha empleado en estudios de ecomorfología al objeto de explicar las adaptaciones ecológicas de las especies al hábitat. Nuestro estudio compara la forma del otolito de diez especies de pargos (familia Lutjanidae) del Golfo Pérsico. El análisis morfológico se realizó a partir de medidas del otolito (longitud, anchura, perímetro, área y peso) y la proporción entre el área del sulcus acusticus y del otolito (S:O). También se analizaron los contornos de los otolitos mediante descriptores matemáticos denominados wavelets. Las variaciones morfológicas en los otolitos se asociaron a la morfología y la coloración externa de los pargos, así como a diversos caracteres ecológicos. Las especies con valores más elevados en la proporción S:O habitan en aguas someras. El análisis multivariante categórico de factores, ecológicos y morfológicos del otolito (forma y tamaño), puso de manifiesto que las especies adaptadas a condiciones tenues de luz presentan el perímetro del otolito más grande. El análisis de varianza del contorno del otolito reveló la presencia de zonas con gran variabilidad inter-específica, si bien solo la parte antero-dorsal permitió distinguir patrones claros de variación. Aunque dichos patrones parecen tener un componente filogenético, también estarían relacionados con el ritmo de actividad diaria o las condiciones de luminosidad en las que viven las especies. Los resultados del este estudio demuestran que la variación morfológica del otolito puede ser usada para explicar la coexistencia de especies simpátricas.

Palabras clave: otolito; morfología; biodiversidad; ecología funcional; pargos; Lutjanidae.

Citation/Como citar este artículo: Sadighzadeh Z., Otero-Ferrer J.L., Lombarte A., Fatemi M.R., Tuset V.M. 2014. An approach to unraveling the coexistence of snappers (Lutjanidae) using otolith morphology. Sci. Mar. 78(3): 353-362. doi: http://dx.doi.org/10.3989/scimar.03982.16C

Editor: E. Massutí.

Received: November 6, 2013. Accepted: April 29, 2014. Published: July 16, 2014.

Copyright: (c) 2014 CSIC. This is an open-access article distributed under the Creative Commons Attribution-Non Commercial Lisence (by-nc) Spain 3.0. 


\section{INTRODUCTION}

Sensory ecology acts as the interface between processes occurring within organisms and those occurring between organisms and their environment (Weissburg 2005). Fishes have a variety of sensory receptors that enable them to glean information from their surroundings (Atema et al. 1988). Among these receptors, the inner ear is associated with balance and sound detection (Popper and Fay 1993, Popper and Lu 2000). Usually, fishes are classified as hearing generalists if they can detect sound frequencies no greater than 1 to $1.5 \mathrm{kHz}$; they are classified as hearing specialists if they can detect sound frequencies greater than $1.5 \mathrm{kHz}$ (Popper et al. 2003). Morphologically, the inner ear of teleostean fishes is essentially formed by three semicircular canals and otolithic organs (sacculus, utriculus and lagena), within which are located the otoliths (sagitta, lapillus and asteriscus, respectively) (Assis 2003, 2005, Cermeño et al. 2006). The otoliths are acellular concretions of calcium carbonate and other inorganic salts developing over a protein matrix (Carlström 1963, Blacker 1969, Degens et al. 1969) and in close association with the sensorial macula (Platt and Popper 1981, Lychakov and Rebane 2000, Schulz-Mirbach et al. 2011). The otoliths, especially the sagittae, play an important role in inner ear functions (Platt and Popper 1981, Popper and Fay 1993, Popper and Lu 2000). Previous studies have indicated that the size of the sagittae is an adaptive factor associated with sensitivity to sound (Myrberg 1980, Montgomery and Pankhurst 1997, Paxton 2000, Cruz and Lombarte 2004). Fishes with large otoliths produce sounds and show highly developed intraspecific acoustic communication (Luczkovich et al. 1999, Holt 2002). These characteristics enable them to live in coastal and deep environments where visual and light communications are less important (Deng et al. 2011, 2013). Moreover, it has been reported that females can use the auditory sense to detect and locate vocalizing males during the breeding season and can change their hearing sensitivity depending on their reproductive status (e.g. Winn 1967, Sisneros and Bass 2003).

Many fishes vary morphologically among habitats. The variations depend on hydrostatic conditions, visibility, intraspecific competition, buoyancy and predation (Robinson and Wilson 1994, Jonsson and Jonsson 2001). Ecomorphology tries to understand how the ecology and evolutionary processes of an organism are related to its morphology (Luczkovich et al. 1995, Wainwright and Bellwood 2002). Most ecomorphological studies are focused on feeding mechanisms (Wainwright et al. 2001, Collar and Wainwright 2009) and locomotion patterns (Robinson and Wilson 1994, Pakkasmaa and Piironen 2000) because these factors may play a role in shaping the patterns of abundance and habitat distribution in fishes (Mittelbach 1984, Wainwright 1996). However, this scientific discipline has also been applied in otolithology because certain characteristics of otoliths (e.g. sulcus area, depth of the sulcus, sulcus area:otolith area ratio or shape) vary according to environmental, ontogenetic, phylogenetic and ecological factors (e.g. Nolf 1985, Lombarte 1992, Lombarte and Lleonart 1993, Paxton 2000, Gauldie and Crampton 2002, Volpedo and Echeverria 2003, Lombarte and Cruz 2007, Tuset et al. 2010, Reichenbacher et al. 2007, Lombarte et al. 2010, Teimori et al. 2012). However, it is not known how otolith shape variability affects hearing ability (Popper and Lu 2000, Popper et al. 2005).

The snappers (Lutjanidae) are a group of circumtropical fishes comprising 23 genera and 123 species (Froese and Pauly 2011). Twelve species of snappers have been identified along the Iranian coasts of the Persian Gulf and the Oman Sea (Assadi and Dehgani 1997, Valinassab et al. 2010). Ecologically, snappers play an important role in near-shore systems, including mangroves, seagrass beds and freshwater streams, and in open-water habitats, inside or around reefs (Aiken 1993, Appeldoorn and Meyers 1993, Cervigón 1993, Baisre 2000, Claro et al. 2001). These habitats play different roles in development and life history by serving as daytime refuges, feeding nurseries and/or nesting areas for many species, including snappers. They also offer pre-recruits and juveniles abundant food resources, less competition with adults and less predation (Druzhinin 1970, Thayer and Chester 1989, Nagelkerken et al. 2001, Cocheret et al. 2003). Recently, Sadighzadeh et al. (2012) demonstrated that otolith shape descriptors and morphometrics are useful for discriminating among Lutjanus species in the Persian Gulf. In this study, a novel methodology for analysing otoliths based on outline sections is developed.

\section{MATERIALS AND METHODS}

\section{Sampling}

Juvenile (close to the size of first maturity, according to the literature) and adult fishes were collected with bottom traps from January 2010 to December 2011 in the Persian Gulf commercial fishery (Fig. 1). A total of ten species of snappers Lutjanus spp. were collected and measured (total length, TL in $\mathrm{cm}$ ). The sagittal otoliths were removed, washed, dried and stored in labeled plastic vials. Otoliths from the left side of the fish were oriented with the inner side (sulcus acusticus) up and digitized using a microscope attached to an image analyser. Large otoliths were directly digitized using a digital camera (Canon 450D with 24-105 mm lens). All images included an embedded millimeter scale (Fig. 2).

\section{Otolith morphometry}

The area $\left(\mathrm{OA}\right.$ in $\left.\mathrm{mm}^{2}\right)$, height $(\mathrm{OH}$ in $\mathrm{mm})$, length (OL in $\mathrm{mm}$ ), perimeter (OP in $\mathrm{mm}$ ) and sulcus acusticus area (related to sensory macula area) (SA in $\mathrm{mm}^{2}$ ) were measured using Image-Pro Plus version 4.1.0 software (Media Cybernetics, Inc.). The otolith weight (OW in $\mathrm{mg}$ ) was also obtained and included in the analysis (Table 1). Kolmogorov-Smirnov and Levene tests were used to check normality of the data distributions and variance homogeneity, respectively. The 

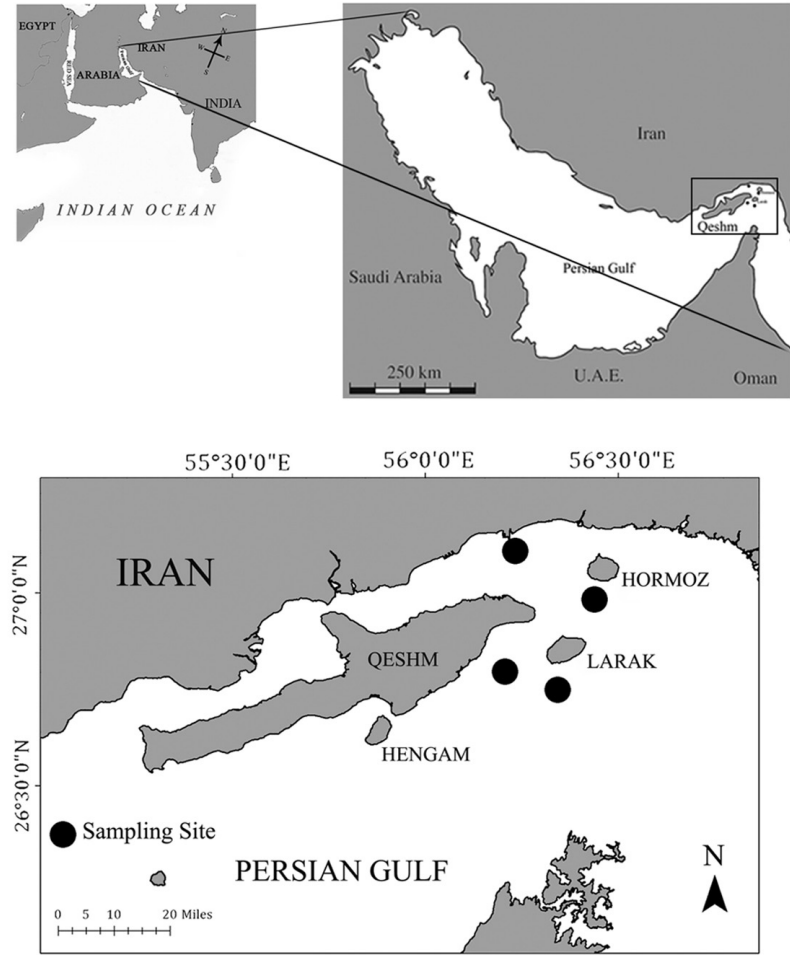

Fig. 1. - Map of the Persian Gulf (NE Indian Ocean) showing the study area where snappers were collected.

relationships between the fish length $(\mathrm{X})$ and otolith variables $(\mathrm{Y})$ were estimated using the power equation $\mathrm{Y}=\mathrm{aX} \mathrm{X}^{\mathrm{b}}$, which was $\log$ transformed to estimate a and b with a simple linear regression. A one-way analysis of variance (ANOVA) was applied to compare the slopes (b) among species using a post hoc Tukey test. A one-way ANOVA was used to compare the ratio between the sulcus acusticus area and otolith area (S:O) among species (Gauldie 1988, Lombarte 1992). In all cases, variances were unequal at the $95 \%$ confidence level. Because the assumption of equal variances was rejected, Tamhane's T2 was used as a post hoc test. The statistical analyses were performed with the SPSS statistical package (SPSS Inc. 2010).

\section{Interaction between otolith size and environment}

To test the relevance of otolith size to the ecological role of snappers in the ecosystem, a multivariate analysis was performed with a categorical principal component analysis (CatPCA) (SPSS Inc. 2010). This procedure simultaneously quantified categorical variables and reduced the dimensionality of the data. A two-dimensional plot was then created to represent the morphological similarity of the categorical variables among snappers. The similarity between the variables was assessed on a nominal and numerical scale using the categories created at data collection (Meulman and Heiser 2005) (Table 2).

A principal component analysis (PCA) was conducted with the morphometric measurements (OA, $\mathrm{OH}, \mathrm{OL}, \mathrm{OP}$ and $\mathrm{SA}$ ) of the otoliths from all specimens to avoid multicollinearity. First, the effect of

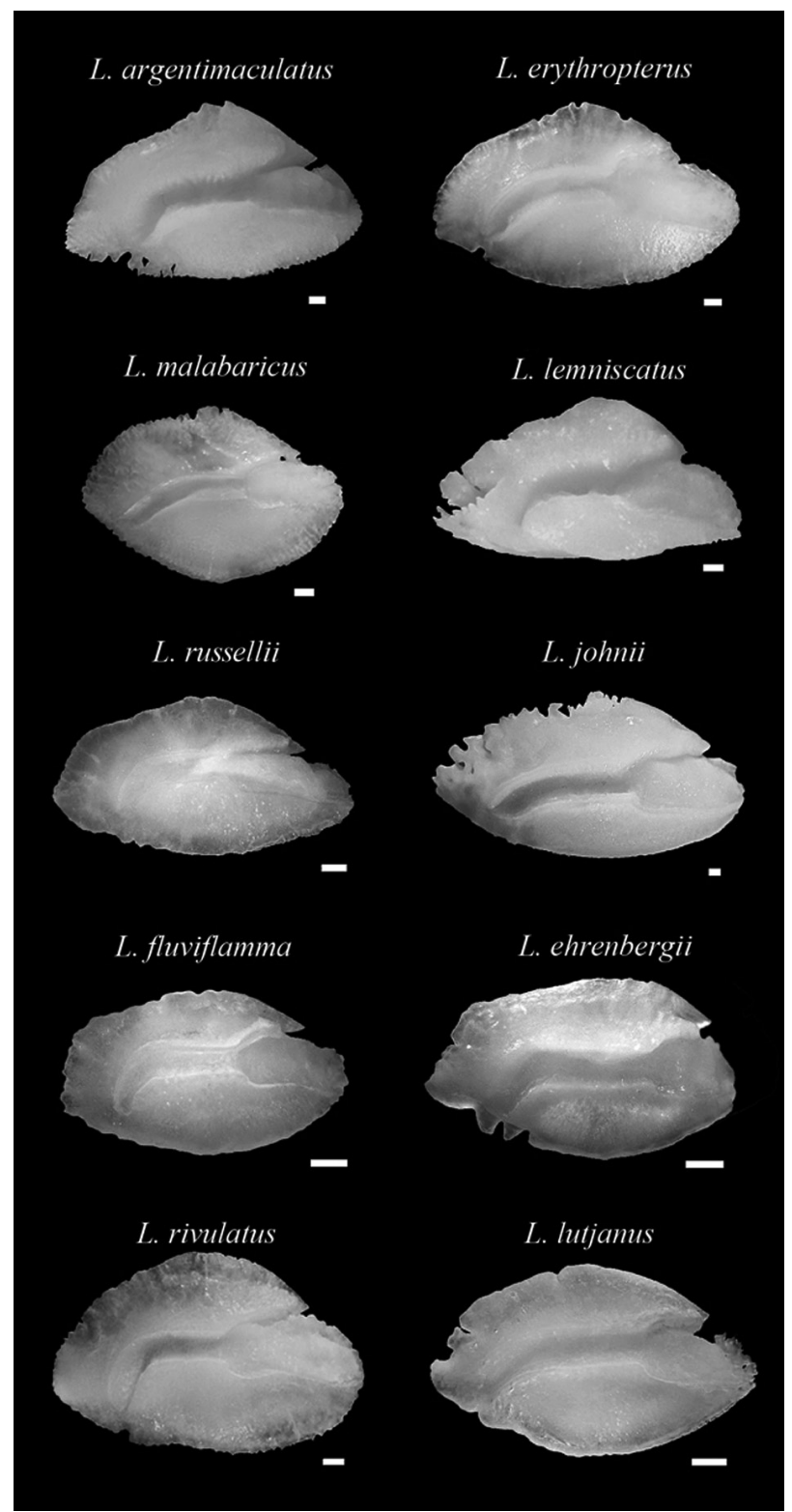

Fig. 2. - Sagittal otoliths of each species of snapper. Scale bars: 1 $\mathrm{mm}$.

fish size on the otolith variables was removed according to Lombarte and Lleonart (1993). The mean value of the variables for each species was then used in the PCA. Thus, the factors obtained were rescaled by dividing each observed value by the minimum value observed for that feature, yielding categorical values between 1 and 10. In addition, the following variables were also included in the CatPCA: visual field (adapted to light or dim light; species with nocturnal activity and species inhabiting turbid or deep habitats are considered species adapted to dim light conditions), environment (marine or euryhaline), depth distribution (coastal, deep or both), life history pattern (groups or primarily solitary) and visually contrasting markings (with spots on the body or lacking spots). The depth distribution was split into three categories; the remaining variables were each split into two categories. The ecological characteristics of each species are given in Table 2 . 
Table 1. - Summary of descriptive statistics of fish length and otolith size of snappers from the Persian Gulf. L. argentimaculatus, Larg; $L$. ehrenbergii, Lehr; L. erythropterus, Lery; L. fulviflamma, Lflu; L. johnii, Ljoh; L. lemniscatus, Llem; L. lutjanus, Llut; L. malabaricus, Lmal; L. rivulatus, Lriv; L. russellii, Lrus.

\begin{tabular}{|c|c|c|c|c|c|c|}
\hline Variables & & Larg & Lehr & Lery & Lflu & Ljoh \\
\hline \multirow{2}{*}{ Total length } & $\min -\max$ & $423-802$ & $146-260$ & $316-523$ & $176-260$ & $167-754$ \\
\hline & mean \pm sd & $648.2 \pm 99.5$ & $203.1 \pm 22.5$ & $370.7 \pm 61.7$ & $206.27 \pm 27.9$ & $364.0 \pm 115.9$ \\
\hline \multirow{2}{*}{ Otolith area } & $\min -\max$ & $67.8-174.7$ & $18.12-40.1$ & $61.6-113.1$ & $22.1-36.7$ & $30.3-313.1$ \\
\hline & mean \pm sd & $123.7 \pm 31.6$ & $29.6 \pm 5.2$ & $74.5 \pm 15.6$ & $27.67 \pm 5.21$ & $98.1 \pm 47.6$ \\
\hline \multirow{3}{*}{ Otolith height } & $\min -\max$ & $7.4-12.5$ & $3.8-5.7$ & $7.7-10.0$ & $4.3-5.5$ & $5.1-15.5$ \\
\hline & mean \pm sd & $10.5 \pm 1.62$ & $4.8 \pm 0.4$ & $8.4 \pm 0.7$ & $4.7 \pm 0.5$ & $8.7 \pm 1.9$ \\
\hline & $\min -\max$ & $12.7-20.5$ & $6.5-10.4$ & $11.7-16.3$ & $7.3-9.8$ & $8.4-28.8$ \\
\hline Otolith length & mean \pm sd & $17.0 \pm 2.4$ & $8.6 \pm 0.8$ & $12.9 \pm 1.4$ & $8.2 \pm 0.8$ & $15.1 \pm 3.8$ \\
\hline \multirow{2}{*}{ Otolith perimeter } & $\min -\max$ & $37.5-61.6$ & $18.9-29.2$ & $34.1-46.5$ & $20.5-26.5$ & $24.1-92.7$ \\
\hline & mean \pm sd & $52.3 \pm 7.5$ & $24.7 \pm 2.3$ & $37.2 \pm 3.8$ & $23.4 \pm 2.4$ & $43.3 \pm 11.4$ \\
\hline \multirow{2}{*}{ Otolith weight } & $\min -\max$ & $0.16-0.83$ & $0.03-0.11$ & $0.15-0.38$ & $0.04-0.11$ & $0.05-2.20$ \\
\hline & mean \pm sd & $0.47 \pm 0.22$ & $0.06 \pm 0.02$ & $0.21 \pm 0.07$ & $0.07 \pm 0.03$ & $0.34 \pm 0.29$ \\
\hline \multirow{2}{*}{ Aspect ratio } & $\min -\max$ & $0.55-0.69$ & $0.51-0.61$ & $0.61-0.68$ & $0.53-0.64$ & $0.53-0.66$ \\
\hline & mean \pm sd & $0.62 \pm 0.05$ & $0.55 \pm 0.02$ & $0.65 \pm 0.02$ & $0.58 \pm 0.03$ & $0.58 \pm 0.03$ \\
\hline \multirow[t]{2}{*}{ Number } & & 13 & 61 & 9 & 11 & 93 \\
\hline & & Llem & Llut & Lmal & Lriv & Lrus \\
\hline \multirow{3}{*}{ Total length } & $\min -\max$ & $298-514$ & $153-232$ & $235-732$ & $405-667$ & $150-372$ \\
\hline & mean \pm sd & $379.8 \pm 61.7$ & $195.7 \pm 19.7$ & $317.6 \pm 86.0$ & $484.9 \pm 84.0$ & $250.8 \pm 54.4$ \\
\hline & $\min -\max$ & $44.5-92.4$ & $19.5-37.4$ & $39.4-359.5$ & $98.8-175.7$ & $15.5-58.7$ \\
\hline Otolith area & mean \pm sd & $63.4 \pm 14.7$ & $29.4 \pm 5.3$ & $86.3 \pm 51.0$ & $119.6 \pm 23.4$ & $34.6 \pm 11.2$ \\
\hline \multirow{2}{*}{ Otolith height } & $\min -\max$ & $5.9-8.7$ & $3.9-5.5$ & $5.9-17.3$ & $9.3-12.5$ & $3.5-7.0$ \\
\hline & mean \pm sd & $7.1 \pm 0.9$ & $4.8 \pm 0.4$ & $8.9 \pm 1.9$ & $10.4 \pm 1.0$ & $5.1 \pm 0.9$ \\
\hline \multirow[b]{2}{*}{ Otolith length } & $\min -\max$ & $10.2-15.6$ & $6.8-9.8$ & $9.2-30.2$ & $14.6-19.5$ & $6.5-12.5$ \\
\hline & mean \pm sd & $12.8 \pm 1.5$ & $8.5 \pm 0.9$ & $13.3 \pm 3.3$ & $16.0 \pm 1.5$ & $9.6 \pm 1.7$ \\
\hline \multirow{2}{*}{ Otolith perimeter } & $\min -\max$ & $29.2-46.7$ & $19.4-28.5$ & $25.9-86.2$ & $42.9-58.3$ & $18.9-33.6$ \\
\hline & mean \pm sd & $35.6 \pm 4.7$ & $24.5 \pm 2.6$ & $39.8 \pm 10.1$ & $48.5 \pm 4.4$ & $26.7 \pm 4.2$ \\
\hline \multirow{2}{*}{ Otolith weight } & $\min -\max$ & $0.10-0.40$ & $0.04-0.11$ & $0.10-2.45$ & $0.33-0.86$ & $0.02-0.16$ \\
\hline & mean \pm sd & $0.18 \pm 0.08$ & $0.07 \pm 0.02$ & $0.29 \pm 0.36$ & $0.45 \pm 0.17$ & $0.07 \pm 0.03$ \\
\hline \multirow{2}{*}{ Aspect ratio } & $\min -\max$ & $0.51-0.62$ & $0.54-0.60$ & $0.57-0.72$ & $0.63-0.68$ & $0.47-0.58$ \\
\hline & mean \pm sd & $0.55 \pm 0.03$ & $0.57 \pm 0.02$ & $0.67 \pm 0.03$ & $0.65 \pm 0.02$ & $0.54 \pm 0.02$ \\
\hline Number & & 23 & 23 & 47 & 12 & 32 \\
\hline
\end{tabular}

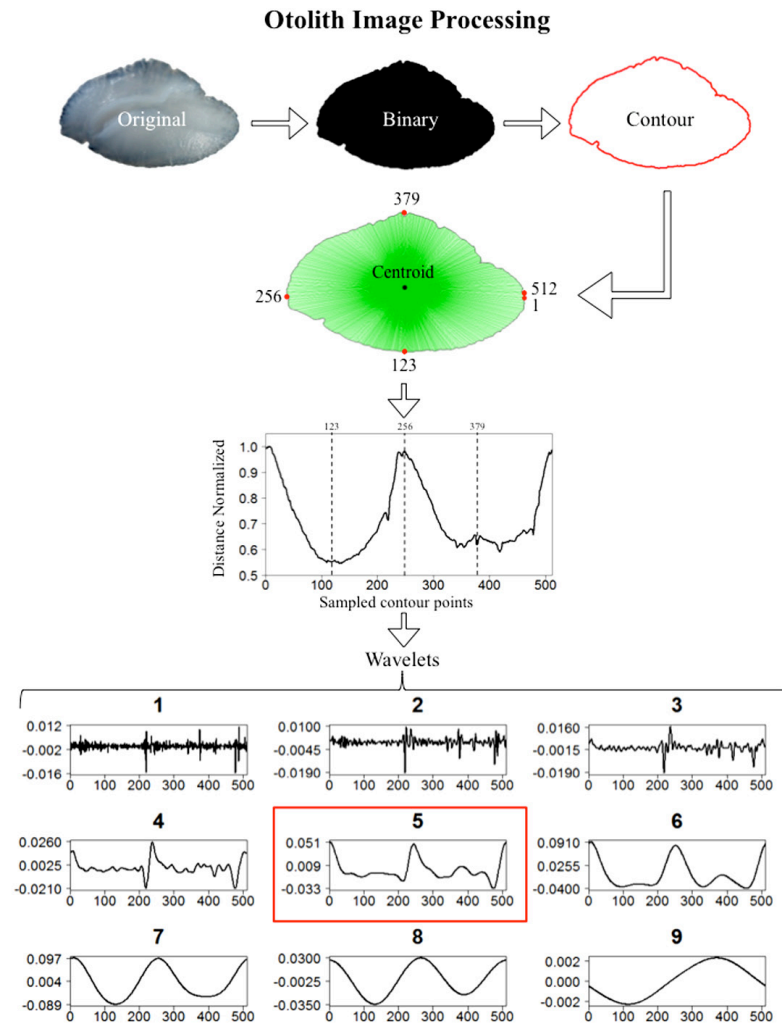

Fig. 3. - Scheme showing the procedure for obtaining wavelets.

\section{Otolith contour}

The analysis of otolith shape was based on a mathematical descriptor, a wavelet $(W T)$, related to the one-dimensional decomposition of the contour (Fig. 3 ). This procedure is based on expanding the contour into a family of functions obtained as the dilations and translations of a unique function known as a mother wavelet (Mallat 1991):

$$
\psi_{s}(x)=\frac{1}{s} \psi\left(\frac{\varphi}{s}\right),
$$

where $\Psi_{s}$ is a function with a support occupying a limited range of the abscissa; choosing its shape adequately and setting a scaling parameter $(s)$ allows the wavelet transform to detect singularities of different sizes in the function analysed. These functions describe the most prominent features of the curve (sharp transitions) in both space and wave number (Fig. 3) (Parisi-Baradad et al. 2005, 2010). To obtain the wavelets, a total of 512 Cartesian coordinates on each of the orthogonal projections of the otolith were extracted using Age \& Shape software (Infaimon SL, Spain). Wavelet functions from 1 to 3 gave details of small variations of the otolith contour, whereas wavelet functions between 7 and 9 showed few contour features. Wavelet number 5 was selected as an intermediate function (Fig. 3). It was also used in a previous study to discriminate Lutjanus species (Sadighzadeh et al. 2012).

A graphical feature, the wavelet variance, was used for all species to find zones with higher variability that 
Table 2. - Summary of ecological, functional, morphological and feeding characteristics of snappers in the Persian Gulf according to Allen (1985), Kuiter and Tonozuka (2001).

\begin{tabular}{|c|c|c|c|c|c|c|c|c|}
\hline Species & $\begin{array}{l}\text { Environ- } \\
\text { ment }\end{array}$ & $\begin{array}{c}\text { Stage } \\
\text { ontogenic }\end{array}$ & Habitat & Depth & $\begin{array}{l}\text { Visual } \\
\text { field }\end{array}$ & $\begin{array}{c}\text { Life } \\
\text { pattern }\end{array}$ & Feeding habits & $\begin{array}{c}\text { Colouration and visual } \\
\text { contrasting marks }\end{array}$ \\
\hline \multirow[t]{2}{*}{ L. argentimaculatus } & \multirow[t]{2}{*}{ Euryhaline } & Juvenile & $\begin{array}{l}\text { Mangroves, } \\
\text { freshwater streams, } \\
\text { tidal creeks }\end{array}$ & Coastal & \multirow[t]{2}{*}{$\begin{array}{l}\text { Dim } \\
\text { light }\end{array}$} & \multirow[t]{2}{*}{ Groups } & \multirow[t]{2}{*}{$\begin{array}{l}\text { Fishes and } \\
\text { crustaceans }\end{array}$} & \multirow{2}{*}{$\begin{array}{l}\text { Greenish brown on } \\
\text { back, grading to reddish } \\
\text { on sides and ventral } \\
\text { parts. No spots }\end{array}$} \\
\hline & & Adult & Reef and mangroves & Deep & & & & \\
\hline L. ehrenbergii & Euryhaline & All & $\begin{array}{c}\text { Coast and freshwater } \\
\text { stream }\end{array}$ & Coastal & Light & Groups & $\begin{array}{l}\text { Fishes and } \\
\text { invertebrates }\end{array}$ & $\begin{array}{l}\text { Often with a series of } \\
\text { four or five narrow } \\
\text { yellow stripes on the } \\
\text { sides below the lateral } \\
\text { line. Spots }\end{array}$ \\
\hline L. erythropterus & Marine & Juvenile & $\begin{array}{l}\text { Muddy substrates } \\
\text { Trawling grounds } \\
\text { and reefs }\end{array}$ & Coastal & $\begin{array}{l}\text { Dim } \\
\text { light }\end{array}$ & Groups & $\begin{array}{l}\text { Fishes, } \\
\text { crustaceans and } \\
\text { cephalopods }\end{array}$ & No spots \\
\hline \multirow[t]{2}{*}{ L. fulviflamma } & \multirow[t]{2}{*}{ Euryhaline } & Juvenile & $\begin{array}{l}\text { Mangroves, } \\
\text { freshwater streams, } \\
\text { tidal creeks }\end{array}$ & \multirow[t]{2}{*}{ Coastal } & \multirow[t]{2}{*}{ Light } & \multirow[t]{2}{*}{ Groups } & \multirow{2}{*}{\multicolumn{2}{|c|}{$\begin{array}{l}\text { A series of six or seven } \\
\text { s, horizontal yellow stripes } \\
\text { ir runs on the side, mainly } \\
\text { below the lateral line. } \\
\text { Spots }\end{array}$}} \\
\hline & & Adult & Reef & & & & & \\
\hline L. johnii & Euryhaline & $\begin{array}{c}\text { Juvenile } \\
\text { Adult }\end{array}$ & $\begin{array}{c}\text { Mangroves } \\
\text { Reef }\end{array}$ & $\begin{array}{l}\text { Coastal } \\
\text { Deep }\end{array}$ & Light & Groups & $\begin{array}{c}\text { Fishes, shrimps, } \\
\text { crabs and } \\
\text { cephalopods }\end{array}$ & $\begin{array}{c}\text { Generally yellow with a } \\
\text { bronze to silvery sheen. } \\
\text { A large black spot }\end{array}$ \\
\hline L. lemniscatus & Marine & Adult & $\begin{array}{l}\text { Offshore reef and } \\
\text { muddy habits }\end{array}$ & Deep & $\begin{array}{l}\text { Dim } \\
\text { light }\end{array}$ & Solitary & $\begin{array}{l}\text { Fishes and } \\
\text { invertebrates }\end{array}$ & $\begin{array}{c}\text { Gray-brown or olive. No } \\
\text { spots }\end{array}$ \\
\hline L. lutjanus & Marine & Adult & $\begin{array}{l}\text { Offshore reef and } \\
\text { trawling grounds }\end{array}$ & Deep & Light & Groups & $\begin{array}{l}\text { Fishes and } \\
\text { crustaceans }\end{array}$ & $\begin{array}{l}\text { Generally silvery white, } \\
\text { with a broad yellow } \\
\text { stripe running along the } \\
\text { side from the eye to the } \\
\text { caudal fin base. No spots }\end{array}$ \\
\hline L. malabaricus & Marine & $\begin{array}{c}\text { Juvenile } \\
\text { Adult }\end{array}$ & $\begin{array}{c}\text { shallow inshores } \\
\text { Offshore reef }\end{array}$ & $\begin{array}{l}\text { Coastal } \\
\text { Deep }\end{array}$ & $\begin{array}{l}\text { Dim } \\
\text { light }\end{array}$ & Groups & $\begin{array}{l}\text { Fishes, } \\
\text { crustaceans and } \\
\text { cephalopods }\end{array}$ & No spots \\
\hline L. rivulatus & Marine & Adult & $\begin{array}{l}\text { Reefs, shallow flats, } \\
\text { coastal slopes }\end{array}$ & $\begin{array}{c}\text { Coastal } \\
\text { and deep }\end{array}$ & Light & Groups & $\begin{array}{l}\text { Fishes, } \\
\text { crustaceans and } \\
\text { cephalopods }\end{array}$ & $\begin{array}{l}\text { Large adults brownish to } \\
\text { grey. No spots }\end{array}$ \\
\hline \multirow{2}{*}{ L. russellii } & \multirow{2}{*}{ Euryhaline } & Juvenile & $\begin{array}{c}\text { Mangroves, } \\
\text { freshwater streams }\end{array}$ & Coastal & \multirow{2}{*}{ Light } & \multirow{2}{*}{ Groups } & \multirow{2}{*}{$\begin{array}{l}\text { Fishes and } \\
\text { invertebrates }\end{array}$} & \multirow{2}{*}{$\begin{array}{l}\text { Whitish or pink with } \\
\text { silvery sheen. Spots }\end{array}$} \\
\hline & & Adult & $\begin{array}{c}\text { Offshore and inshore } \\
\text { reefs }\end{array}$ & Deep & & & & \\
\hline
\end{tabular}

could indicate different patterns in the shape of the otolith. To determine whether this variability could group the species, a cluster analysis was performed based on quadratic Euclidean distance using Ward's method. To detect significant differences between the mean functions of groups, an ANOVA test was applied based on the analysis of randomly chosen one-dimensional projections (Cuesta-Albertos and Febrero-Bande 2010). This test is implemented in the function anova.RPm in the R library fda.usc (Febrero-Bande and Oviedo de la Fuente 2011). The p-values were obtained using 1000 bootstrap replicates.

\section{RESULTS}

\section{Otolith morphometric analysis}

All morphometric variables of the sagittal otoliths showed a good relationship with fish length for each species, with more than $75 \%$ of the variance explained, independently of sample size. Otolith area was the variable with the strongest relationship to fish length $\left(r^{2}>0.870\right)$, whereas the variation in otolith height was more diverse among species (Table 3). The comparison of slopes showed no specific differences among species for any variables except in the case of $L$. rivulatus (Table 4). However, the comparisons based on the $\mathrm{S}$ :O ratio (Tamhane's T2 test, $\mathrm{p}>0.05$ ) clustered the species into six groups in decreasing order of relative size (major to minor): 1) L. lutjanus, 2) L. ehrenbergii and L. fulviflam$m a, 3) L$. fulviflamma and L. russellii, 4) L. malabaricus, L. lemniscatus and $L$. johnii, 5) L. erythropterus and $L$. rivulatus, and 6) L. argentimaculatus (Fig. 4).

The PCA reduced the otolith dimensions to two sets, OTO1 and OTO2, which were related to the otolith perimeter. The two-dimensional plot of the CatPCA analysis indicated that the first dimension was primarily influenced by environment, visually contrasting markings, the depth distribution and the otolith perimeter. The second dimension was influenced by the otolith morphometry (OTO1) and the visual field (Fig. 5). The total variance explained by the model was $65.8 \%$, including $45.9 \%$ along the first dimension and $19.9 \%$ along the second. The increase in the depth distribution of the species was positively related to the absence of a spot (visually contrasting markings) on the body of 
Table 3. - Power relationships between fish length and otolith variables for snappers from the Persian Gulf. OA, otolith area; OH, otolith height; OL, otolith length; OP, otolith perimeter; OW, otolith weight; TL, total length.

\begin{tabular}{|c|c|c|c|c|c|c|c|c|c|}
\hline \multicolumn{2}{|c|}{ L. argentimaculatus $(\mathrm{n}=13)$} & \multicolumn{2}{|c|}{ L. ehrenbergii $(\mathrm{n}=61)$} & \multicolumn{2}{|c|}{ L. erythropterus $(\mathrm{n}=9)$} & \multicolumn{2}{|c|}{ L. fulviflamma $(\mathrm{n}=11)$} & \multicolumn{2}{|c|}{ L. johnii $(\mathrm{n}=93)$} \\
\hline Equation & $\mathrm{r}^{2}$ & Equation & $\mathrm{r}^{2}$ & Equation & $\mathrm{r}^{2}$ & Equation & $\mathrm{r}^{2}$ & Equation & $r^{2}$ \\
\hline II 1.616 & 98 & TL 1.485 & 0.870 & 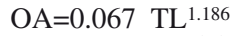 & 0 & 3 TI 1. & 0.908 & 69 & 0.9 \\
\hline & & & & & & & & & \\
\hline & & & & & & & & & \\
\hline & & & & & & & & & \\
\hline & 866 & & 0.8 & & 0. & & & & 70 \\
\hline \multicolumn{2}{|c|}{ L. lemniscatus $(\mathrm{n}=23)$} & \multicolumn{2}{|c|}{ L. lutjanus $(\mathrm{n}=23)$} & \multicolumn{2}{|c|}{ L. malabaricus $(\mathrm{n}=47)$} & \multicolumn{2}{|c|}{ L. rivulatus $(\mathrm{n}=12)$} & \multicolumn{2}{|c|}{ L. russelli $(\mathrm{n}=32)$} \\
\hline & $\mathrm{r}^{2}$ & Equation & $r^{2}$ & Equation & $\mathrm{r}^{2}$ & Equation & $\mathrm{r}^{2}$ & & $r^{2}$ \\
\hline & & & & & & & & & \\
\hline & & & & & & & & & \\
\hline & & & & & & & & & \\
\hline & & & 0.8 & & 0.811 & & & & 0.951 \\
\hline $\mathrm{W}$ & 24 & T 2.46 & 0.745 & O) & 0.894 & OV & 0 & 229 & 0.979 \\
\hline
\end{tabular}

Table 4. - Otolith variables presenting significant differences (Tukey's test) in the slope of relationships between fish length and otolith variables among snappers from the Persian Gulf. ns, not significant; OA, otolith area; $\mathrm{OH}$, otolith height; OL, otolith length; OP, otolith perimeter; $\mathrm{OW}$, otolith weight. Differences are significant $(\mathrm{p}<0.05)$ when otolith variables appear.

\begin{tabular}{|c|c|c|c|c|c|c|c|c|c|c|}
\hline & L.arg & Lehr & Lery & Lflu & Ljoh & Llem & Llut & Lmal & Lriv & Lrus \\
\hline L. argentimaculatus (Larg) & - & & & & & & & & & \\
\hline L. ehrenbergii (Lehr) & $\mathrm{OH}$ & - & & & & & & & & \\
\hline L. erythropterus (Lery) & OW & ns & - & & & & & & & \\
\hline L. fulviflamma (Lflu) & $\mathrm{ns}$ & ns & $\mathrm{ns}$ & - & & & & & & \\
\hline L. johnii (Ljoh) & $\mathrm{ns}$ & $\mathrm{ns}$ & $\mathrm{ns}$ & $\mathrm{ns}$ & - & & & & & \\
\hline L. lemniscatus (Llem) & $\mathrm{ns}$ & ns & $\mathrm{ns}$ & $\mathrm{ns}$ & $\mathrm{ns}$ & - & & & & \\
\hline L. lutjanus (Llut) & $\mathrm{ns}$ & ns & OA & $\mathrm{ns}$ & $\mathrm{ns}$ & $\mathrm{OL}$ & - & & & \\
\hline L. malabaricus (Lmal) & ns & ns & ns & ns & $\mathrm{ns}$ & $\mathrm{ns}$ & ns & - & & \\
\hline L. rivulatus (Lriv) & $\mathrm{OH}, \mathrm{OP}$ & OP & $\mathrm{OL}$ & ns & $\mathrm{OL}, \mathrm{OP}$ & $\mathrm{ns}$ & OA, OL, OP & $\mathrm{OA}, \mathrm{OL}, \mathrm{OP}$ & - & \\
\hline L. russellii (Lrus) & ns & ns & $\mathrm{ns}$ & ns & $\mathrm{ns}$ & $\mathrm{ns}$ & ns & $\mathrm{ns}$ & OL & - \\
\hline
\end{tabular}

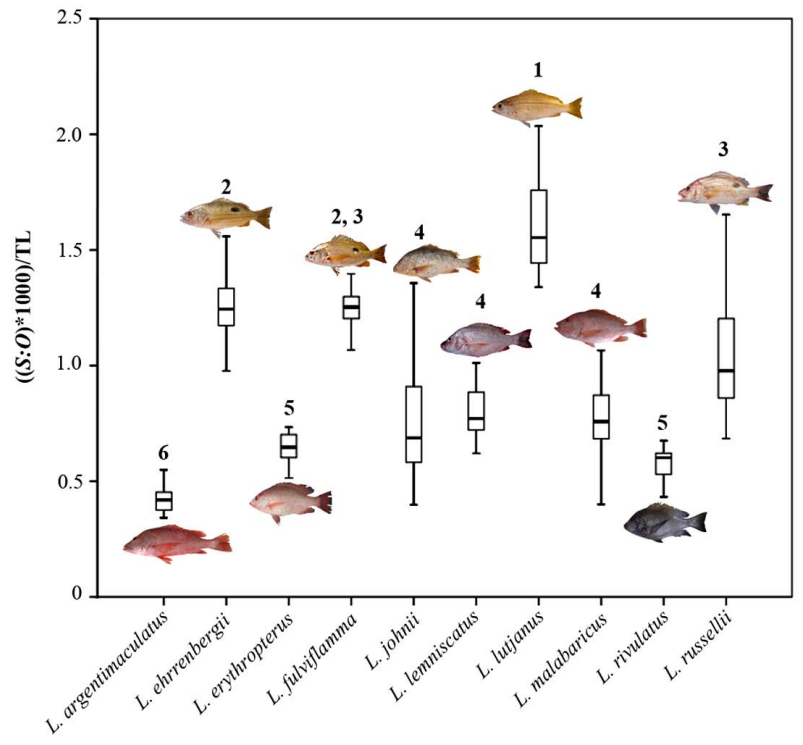

Fig. 4. - Box plots (maximum, minimum, upper and lower quartiles) for the sulcus acusticus area: otolith area ratio ( $\mathrm{S}: \mathrm{O})$ for snappers from the Persian Gulf. Numbers indicate the corresponding group.

the fish. The species adapted to dim light conditions and deeper distribution had a greater otolith perimeter.

\section{Otolith contour}

The graphical illustration of wavelet number 5 showed specific variations associated with prominent features of the otolith contour (Fig. 6). An ANOVA indicated three zones with a high variability (Fig. 7A, B):

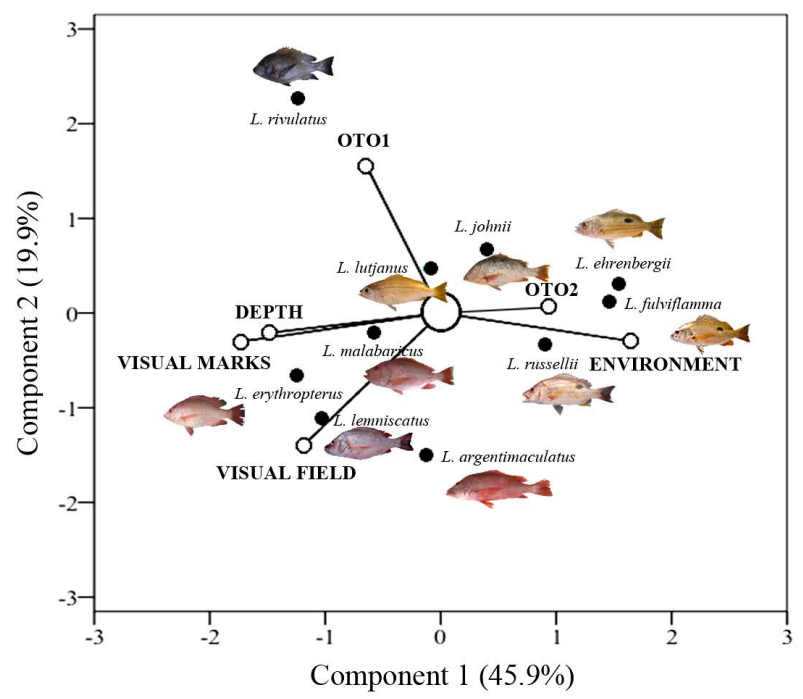

Fig. 5. - Scatterplot of the CatPCA analysis of ecological, functional and morphological factors influencing the ecomorphological distribution of snappers from the Persian Gulf.

posterior, antero-dorsal and excisura ostii. The posterior and excisura ostii zones were associated with development of the rostrum, anti-rostrum and post-rostrum. However, only the antero-dorsal zone of the wavelet (Fig. 7C) showed well-defined patterns. A cluster analysis grouped the species into three significant patterns (ANOVA, p<0.05) (Fig. 8A, B): 1) otoliths with a flattened antero-dorsal zone, e.g. L. ehrenbergii, $L$. fulviflamma, L. lutjanus and L. rivulatus; 2) otoliths with a slight development of the antero-dorsal zone, 


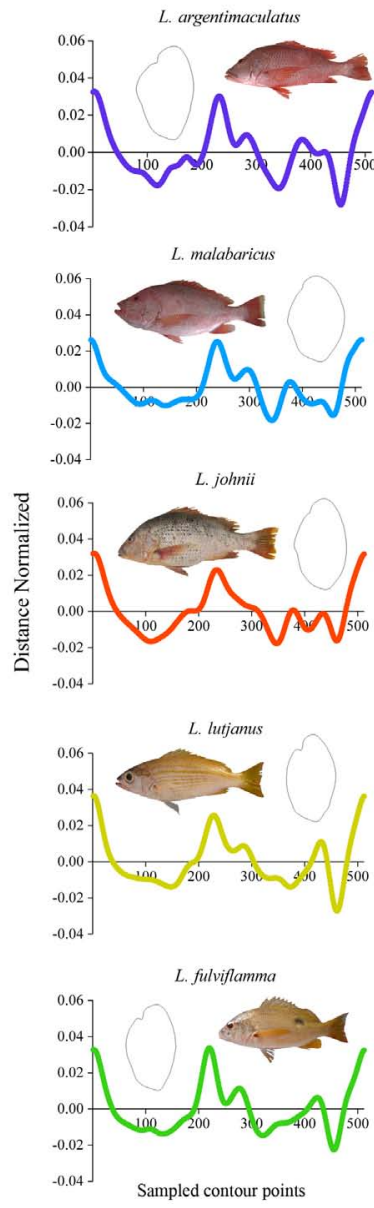

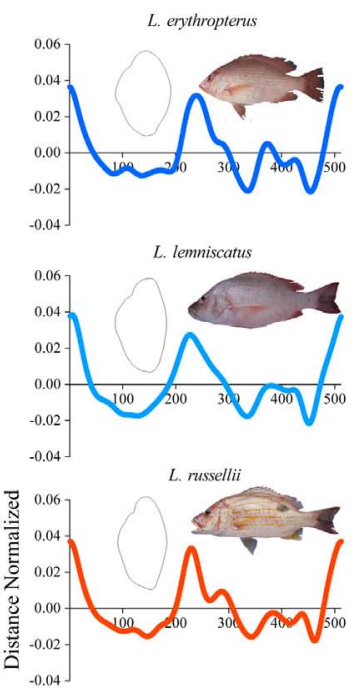
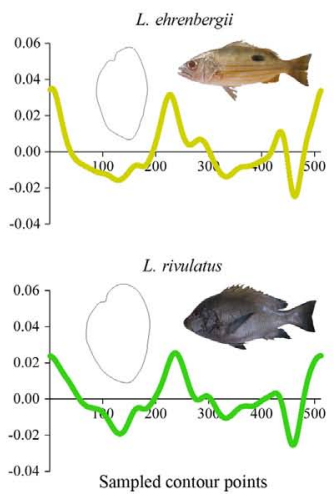

Fig. 6. - Signals of wavelet 5 from the otoliths of snappers from the Persian Gulf. Colours show the similarities between signals.

e.g. L. russellii and L. johnii; and 3) otoliths with an extensive development of the antero-dorsal zone, e.g. L. argentimaculatus, L. erythropterus, L. malabaricus and L. lemniscatus.

\section{DISCUSSION}

The S:O ratio and otolith size are related to the hearing capabilities of marine fishes (Gauldie 1988, Montgomery and Pankhurst 1997) and ecological factors such as depth distribution, fish mobility and differences in food and spatial niches (Lombarte 1992, Aguirre and Lombarte 1999, Tuset et al. 2010). Our results stressed the relevance of the sagittal otolith characteristics to the ecomorphological characteristics, showing otolith shape patterns associated with functional and ecological factors.

Several species groups of snappers are recognized on the basis of morphology and external colouration, e.g. 'blue-lined', 'black spot' complex, 'yellow-lined' or 'red-lined'. These groups are congruent with phylogenetic evolution (Miller and Cribb 2007). The fishes living in shallower water have acquired a tendency to be yellowish with stripes and form aggregations to avoid large predators. They also have larger eyes and bright colour patterns favouring visual communication. The otoliths are small, most likely to avoid the
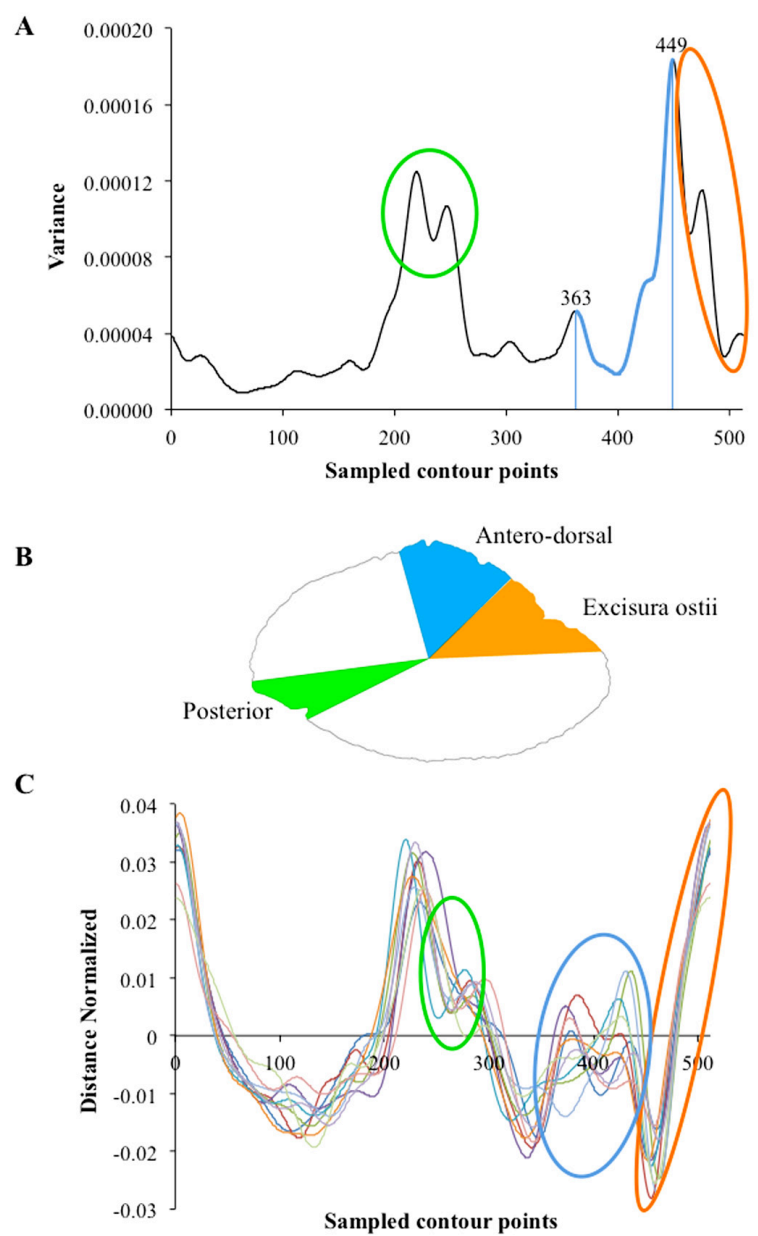

Fig. 7. - Graphics indicating zones with higher variability in wavelet 5. (A) variance for all species, (B) otolith contour, (C) wavelet 5 for each species.

background noise produced by rough seas (Paxton 2000, Volpedo and Echeverria 2003, Cruz and Lombarte 2004). In contrast, species inhabiting deeper or dimly illuminated waters have a darker colouration. Many are solitary, exhibit territorial behaviour, and possess larger otoliths (Volpedo and Echeverria 2003, Cruz and Lombarte 2004, Lombarte et al. 2010). This ecological pattern was clearly noted in the species studied, illustrating the relationship of morphology and external colouration vs. otolith size. Thus, the snappers of the 'black spot' complex and the 'yellow-lined' group (L. ehrenbergii, L. fulviflamma, L. lutjanus and L. russellii), which inhabit shallow waters (Druzhinin 1970, Kuiter and Tonozuka 2001), showed the highest $\mathrm{S}: \mathrm{O}$ ratio and the smallest otolith size. The clade containing the 'red-lined' and 'blue-lined' snappers ( $L$. argentimaculatus, L. erythropterus, L. malabaricus, $L$. lemniscatus, and L. rivulatus), which live in deeper or dimly illuminated waters and have a dark colouration (Allen 1985), showed the lowest S:O ratio and highest otolith size. L. johnii has characteristics common to both groups. Although it should have been closer to the 'black spot' species complex, it is genetically closer to L. erythropterus (Miller and Cribb 2007).

Species inhabiting environments with a limited visual field can increase their hearing capabilities (Lombarte 

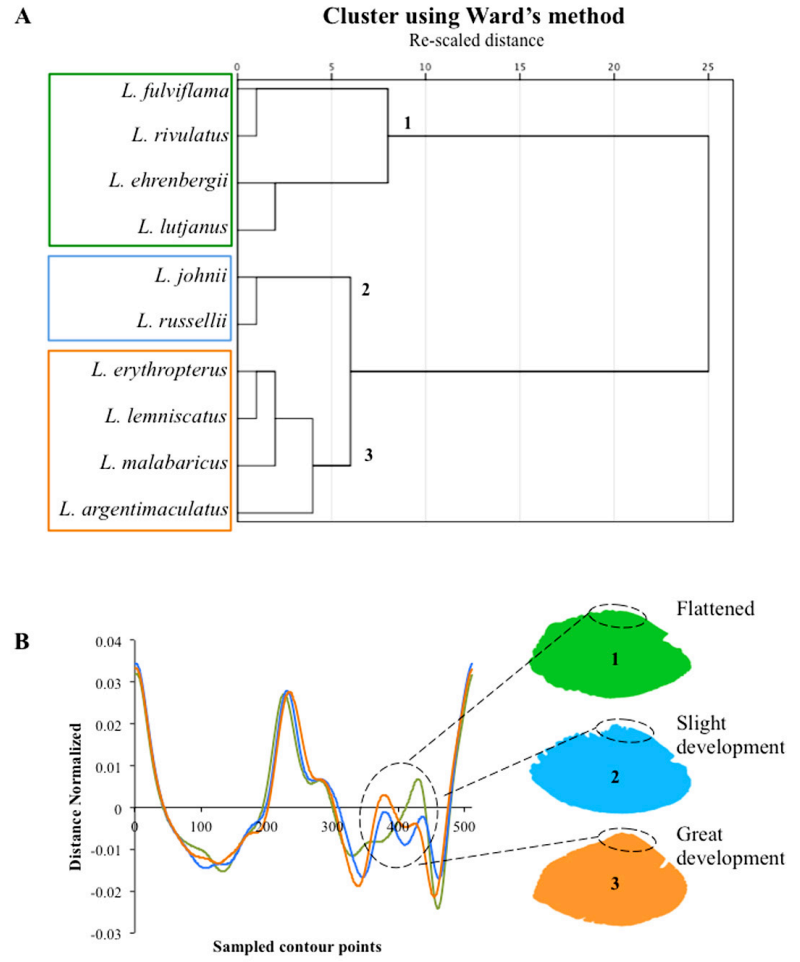

Fig. 8. - A, hierarchical clustering of snappers from the Persian Gulf using antero-dorsal zone; B, mean signal of wavelet 5 for each group showing the morphology of the antero-dorsal zone of the otolith. Numbers indicate the otolith patterns obtained.

and Fortuño 1992, Deng et al. 2013). The development of the ostial area of the sulcus acusticus region of the sagittal otolith is correlated with an increase in the proportion of horizontally oriented sensory hair cells (Popper and Coombs 1982, Ramcharitar et al. 2006), which may help to detect directional acoustic stimuli and to locate prey (Popper and Fay 1993). Moreover, the species that use environments with dim illumination tend to show increases in otolith size and adopt non-visual communication (acoustic or chemical) (Paxton 2000, Cruz and Lombarte 2004). Our study showed a relationship between the variations in the antero-dorsal area of the sagittal otolith of snappers and fish behaviour. A flattened shape was observed in L. rivulatus, which forages during the day, whereas extensive development of the antero-dorsal area was found in L. argentimaculatus, a species that is active at night (Martínez-Andrade 2003). Accordingly, we infer that $L$. argentimaculatus, L. erythropterus, L. malabaricus and L. lemniscatus (all 'red-lined') should be adapted to dim light conditions or nocturnal activity; L. ehrenbergii, L. fulviflamma ('black spot' complex), L. lutjanus ('yellow-lined') and L. rivulatus ('blue-lined') should be more active during the day; whereas $L$. russellii and $L$. johnii ('black spot' complex) should show a nocturnal-diurnal dichotomy. Thus, the diel activity rhythm facilitates coexistence between competitors extending beyond the effects of adaptation to different behavioral strategies and feeding habitats (Colmenero et al. 2010, Fox and Bellwood 2011, Azzurro et al. 2013).

The results presented here demonstrate that wavelet analysis is a very useful mathematical procedure for ecomorphological studies in addition to its use in species discrimination (Parisi-Baradad et al. 2005, 2010, Sadighzadeh et al. 2012). The identification of otolith zones with high morphological variability implies that information on shape of the whole otolith may not be necessary for the identification of stocks or species or for ontogenetic or ecomorphological studies. These findings constitute a novel approach to species discrimination. Finally, discrimination of the activity of fishes will be essential for a better understanding of ecosystem functioning and the ecological roles played by fish species (Pulcini et al. 2008, Colmenero et al. 2010, Meakin and Qin 2011, Aguzzi et al. 2013).

\section{ACKNOWLEDGEMENTS}

We would like to thank our colleagues at the Persian Gulf and Oman Sea Ecological Research Institute for their kind collaboration. This study was co-funded by the research project AFORO3D (MICIN CTM2010-1970) of the Spanish Government. We would like to thank the reviewers for their comments and suggestions.

\section{REFERENCES}

Aguirre H., Lombarte A. 1999. Ecomorphological comparisons of sagittae in Mullus barbatus and M. surmuletus. J. Fish. Biol. 55: $105-114$.

http://dx.doi.org/10.1111/j.1095-8649.1999.tb00660.x

Aguzzi J., Sbragaglia V., Santamaría G., et al. 2013. Daily activity rhythms in temperate coastal fishes: insights from cabled observatory video monitoring. Mar. Ecol. Prog. Ser. 486: 223-236. http://dx.doi.org/10.3354/meps10399

Aiken K.A. 1993. Jamaica in Marine Fishery Resources of the Lesser Antilles, Puerto Rico \& Hispaniola. FAO Fish. Tech. Pap. 326: $1160-1180$.

Allen G.R. 1985. FAO Species Catalogue. Snappers of the world. An annotated and illustrated catalogue of lutjanid species known to date. FAO Fish. Syn. 125: 1-208.

Assadi H., Dehghani P.R. 1997. Atlas of the Persian Gulf and the Sea of Oman Fishes. Iranian Fisheries Research and Training Organization, $226 \mathrm{pp}$.

Assis C.A. 2003. The lagenar otoliths of teleosts: their morphology and its application in species identification, phylogeny and systematics. J. Fish Biol. 62: 1268-1295. http://dx.doi.org/10.1046/j.1095-8649.2003.00106.x

Assis C.A. 2005. The utricular otoliths, lapilli, of teleosts: their morphology and relevance for species identification and systematics studies. Sci. Mar. 69: 259-273.

Appeldoorn R.S., Meyers S. 1993. Puerto Rico and Hispaniola. FAO Fish. Tech. Pap. 326: 99-159.

Atema J., Fay R.R., Popper A.N., et al. 1988. Sensory Biology of Aquatic Animals. Springer Verlag, 936 pp. http://dx.doi.org/10.1007/978-1-4612-3714-3

Azzurro E., Aguzzi J., Maynou F., et al. 2013. Diel rhythms in shallow Mediterranean rocky-reef fishes: a chronobiological approach with the help of trained volunteers. J. Mar. Biol. Assoc. U.K. 93: 461-470. http://dx.doi.org/10.1017/S0025315412001166

Baisre J.A. 2000. Chronicle of Cuban marine fisheries (1935-1995). Trend analysis and fisheries potential. FAO Fish. Tech. Pap. 394: 1-26.

Blacker R.W. 1969. Chemical composition of the zones in cod ( $G a$ dus morhua L.) otoliths. J. Cons. Int. Explor. Mer 33: 107-108. http://dx.doi.org/10.1093/icesims/33.1.107

Carlström D. 1963. A crystalographic study of vertebrate otoliths. Biol. Bull. 125: 441-463 http://dx.doi.org/10.2307/1539358

Cermeño P., Morales-Nin B., Uriarte A. 2006. Juvenile European anchovy otolith microstructure. Sci. Mar. 70: 553-557.

Cervigón F. 1993. Los peces marinos de Venezuela. Volume 2. Fundación Científica Los Roques, Caracas, Venezuela, 954 pp. 
Claro R., Lindeman K.C., Parenti L.R. 2001. Ecology of the marine fishes of Cuba. Smithsonian Institution Press, Washington, 253 pp.

Cocheret de la Moriniére E., Pollux B.Y.A., Nagelkerken I., et al. 2003. Diet shifts Caribbean grunts (Haemulidae) and snappers (Lutjanidae) and the relation with nursery-to-coral reef migrations. Estuar. Coast. Shelf Sci. 57: 1079-1089. http://dx.doi.org/10.1016/S0272-7714(03)00011-8

Collar D.C., Wainwright P.C. 2009. Ecomorphology of centrarchid fishes. In: Cook S.J., Philipp D.P. (eds), Centrarchid fishes: diversity, biology and conservation. Blackwell Scientific Press, pp. 70-89. http://dx.doi.org/10.1002/9781444316032.ch3

Colmenero A.I., Aguzzi J., Lombarte A., et al. 2010. Sensory constraints in temporal segregation in two species of anglerfish, Lophius budegassa and L. piscatorius. Mar. Ecol. Prog. Ser. 416: $255-265$. http://dx.doi.org/10.3354/meps08766

Cruz A., Lombarte A. 2004. Otolith size and its relationship with colour patterns and sound production. J. Fish Biol. 65: 1512-1525. http://dx.doi.org/10.1111/j.0022-1112.2004.00558.x

Cuesta-Albertos J.A., Febrero-Bande M. 2010. A simple multiway ANOVA for functional data. Test 19: 537-557. http://dx.doi.org/10.1007/s11749-010-0185-3

Degens E.T., Deuser W.G., Haedrich R.L. 1969. Molecular structure and composition of fish otoliths. Mar. Biol. 2: 105-113. http://dx.doi.org/10.1007/BF00347005

Deng X., Wagner H.J., Popper A.N. 2011. The inner ear and its coupling to the swim bladder in the deep-sea fish Antimora rostrata (Teleostei: Moridae). Deep Sea Res. Part I Oceanogr. Res. Pap. 58: 27-37. http://dx.doi.org/10.1016/j.dsr.2010.11.001

Deng X., Wagner H.J. Popper A.N. 2013. Interspecific variations of inner ear structure in the deep-sea fish family Melamphaidae. Anat. Rec. 296: 1064-1082.

Druzhinin A.D. 1970. The range and biology of snappers (Family Lutjanidae). J. Ichthyol. 10: 717-736.

Febrero-Bande M., Oviedo de la Fuente M. 2011. fda.usc: Functional Data Analysis and Utilities for Statistical Computing (fda.usc). R package version 0.9.5 http://CRAN.R-project.org/package $=$ fda.usc

Fox R.J., Bellwood D.R. 2011. Unconstrained by the clock? Plasticity if diel activity rhythm in a tropical reef fish, Siganus lineatus. Funct. Ecol. 25: 1096-1105. http://dx.doi.org/10.1111/j.1365-2435.2011.01874.x

Froese R., Pauly D. 2011. FishBase. World Wide Web electronic publication. http://www.fishbase.org

Gauldie R.W. 1988. Function, form and time-keeping properties of fish otoliths. Comp. Biochem. Physiol. Part A 91: 395-402. http://dx.doi.org/10.1016/0300-9629(88)90436-7

Gauldie R.W., Crampton J.S. 2002. An ecomorphological explication of individual variability in the shape of the fish otolith: comparison of the otolith of Hoplostethus atlanticus with other species by depth. J. Fish Biol. 60: 1221-1240. http://dx.doi.org/10.1111/j.1095-8649.2002.tb01715.x

Holt S.A. 2002. Intra- and inter-day variability in sound production by red drum (Sciaenidae) at a spawning site. Bioacoustics 12: 227-229. http://dx doi.org/10.1080/09524622.2002.9753704

Jonsson B., Jonsson N. 2001. Polymorphism and speciation in Arctic charr. J. Fish Biol. 58: 605-638. http://dx.doi.org/10.1111/j.1095-8649.2001.tb00518.x

Kuiter R.H., Tonozuka T. 2001. Pictorial guide to Indonesian reef fishes. Part 1 eels-snappers, Muraenidae-Lutjanidae. Zoonetics, Australia, $302 \mathrm{pp}$.

Lombarte A. 1992 Changes in otolith area:sensory area ratio with body size and depth. Environ. Biol. Fish. 33: 405-410. http://dx.doi.org/10.1007/BF00010955

Lombarte A., Cruz A. 2007. Otolith size trends in marine fish communities from different depth strata. J. Fish Biol. 71: 53-76. http://dx.doi.org/10.1111/j.1095-8649.2007.01465.x

Lombarte A., Fortuño J.M. 1992. Differences in morphological features of the sacculus of the inner ear of two hakes (Merluccius capensis and M. paradoxus, Gadiformes) inhabits from different depth of sea. J. Morphol. 214: 97-107. http://dx.doi.org/10.1002/jmor.1052140107

Lombarte A., Lleonart J. 1993. Otolith size changes related with body growth, habitat depth and temperature. Environ. Biol. Fish. 37: 297-306.
http://dx.doi.org/10.1007/BF00004637

Lombarte A., Palmer M., Matallanas J., et al. 2010. Ecomorphological trends and phylogenetic inertia of otolith sagittae in Nototheniidae. Environ. Biol. Fish. 89: 607-618. http://dx doi.org/10.1007/s10641-010-9673-2

Luczkovich J.J., Norton S.R., Gilmore R.G. 1995. The influence of oral anatomy on prey selection during the ontogeny of two percoid fishes, Lagodon rhomboides and Centropomus undecimalis. Environ. Biol. Fish. 44: 79-95. http://dx.doi.org/10.1007/BF00005908

Luczkovich J.J., Sprague M.W., Johnson S.E., et al. 1999. Delimiting spawning areas of weakfish Cynoscion regalis (Family Sciaenidae) in Pamlico Sound, North Carolina using passive hydroacoustic surveys. Bioacoustics 10: 143-160. http://dx.doi.org/10.1080/09524622.1999.9753427

Lychakov D.V., Rebane Y.T. 2000. Otolith regularities. Hear. Res. 143: 83-102. http://dx.doi.org/10.1016/S0378-5955(00)00026-5

Mallat S. 1991. Zero-crossings of a wavelet transform. IEEE Trans. Inform. Theory 37: 1019-1033 http://dx.doi.org/10.1109/18.86995

Martinez-Andrade F. 2003. A comparison of life histories and ecological aspects among snappers (Pisces: Lutjanidae). PhD thesis, Lousiana State University, $194 \mathrm{pp}$.

Meakin C., Qin J. 2011. Growth, behaviour and colour changes of juvenile King George whiting (Silaginodes punctata) mediated by light intensities. New Zealand J. Mar. Freshw. Res. 46: $111-123$ http://dx.doi.org/10.1080/00288330.2011.608687

Meulman J.J., Heiser W.J. 2005. Categories 14.0. CD Rom. SPSS Inc., Chicago.

Miller T.L., Cribb T.H. 2007. Phylogenetic relationships of some common Indo-Pacific snappers (Perciformes: Lutjanidae) based on mitochondrial DNA sequences with comments on the taxonomic position of the Caesioninae. Mol. Phyl. Evol. 44: 450-460.

http://dx.doi.org/10.1016/j.ympev.2006.10.029

Mittelbach G.G. 1984. Predation and resource partitioning in two sunfishes (Centrarchidae). Ecology 65: 499-513. http://dx.doi.org/10.2307/1941412

Montgomery J.C., Pankhurst N.W. 1997. Sensory physiology. In: Randall D.J., Farrell A.P. (eds), Deep-sea Fishes. Academic Press, pp. 325-349. http://dx.doi.org/10.1016/S1546-5098(08)60233-2

Myrberg A.A. Jr. 1980. Fish bioacoustics: its relevance to the 'not so silent world'. Environ. Biol. Fish. 5: 297-304. http://dx.doi.org/10.1007/BF00005184

Nagelkerken I., Kleijnen S., Klop T., et al. 2001. Dependence of Caribbean reef fishes on mangroves and seagrass beds as nursery habitats: a comparison of fish faunas between bays with and without mangroves/seagrass beds. Mar. Ecol. Prog. Ser. 214: $225-235$. http://dx.doi.org/10.3354/meps214225

Nolf D. 1985. Otolithi piscium. In: H.P. Schultze (ed.), Handbook of Paleoichthyology. Gustav Fischer Verlag, pp. 1-10.

Pakkasmaa S., Piironen J. 2000. Water velocity shapes juvenile salmonids. Evol. Ecol. 14: 721-730. http://dx.doi.org/10.1023/A:1011691810801

Parisi-Baradad V., Lombarte A., Garcia-Ladona E., et al. 2005. Otolith shape contour analysis using affine transformation invariant wavelet transforms and curvature scale space representation. Mar. Freshw. Res. 56: 795-804. http://dx.doi.org/10.1071/MF04162

Parisi-Baradad V., Manjabacas A., Lombarte A., et al. 2010. Automated Taxon Identification of Teleost fishes using an otolith online database. Fish. Res. 105: 13-20. http://dx. doi.org/10.1016/j.fishres.2010.02.005

Paxton J.R. 2000. Fish otoliths: do sizes correlate with taxonomic group, habitat and/or luminescence? Phil. Trans. Roy. Soc. London Ser. B 355: 1299-1303. http://dx.doi.org/10.1098/rstb.2000.0688

Platt C., Popper A.N. 1981. Fine structure and function of the ear. In: Tavolga W.N., Popper A.N., Ray R.R. (eds), Hearing and Sound Communication in Fishes. Springer Verlag, pp. 1-36. http://dx.doi.org/10.1007/978-1-4615-7186-5_1

Popper A.N., Coombs S. 1982. The morphology and evolution of the ear in actinopterygian fishes. Amer. Zool. 22: 311-328.

Popper A.N., Fay R.R. 1993. Sound detection and processing by fish: critical review and major research questions. Brain Beh. Evol. 41: 14-38. 
http://dx.doi.org/10.1159/000113821 http://dx.doi.org/10.1159/000316111

Popper A.N., Lu Z. 2000. Structure-function relationships in fish otolith organs. Fish. Res. 46: 15-25. http://dx doi.org/10.1016/S0165-7836(00)00129-6

Popper A.N., Fay R.R., Platt C., et al. 2003. Sound detection mechanisms and capabilities of teleost fishes. In: Tavolga W.N., Popper A.N., Ray R.R. (eds), Hearing and Sound Communication in Fishes. Springer Verlag, pp. 3-38.

Popper A.N., Ramcharitar J., Campana S.E. 2005. Why otoliths? Insights from inner ear physiology and fisheries biology. Mar. Freshw. Res. 56: 497-504. http://dx.doi.org/10.1071/MF04267

Pulcini D., Costa C., Aguzzi J., et al. 2008. Light and shape: A contribution to demonstrate morphological differences in diurnal and nocturnal Teleosts. J. Morph. 269:375-385. http://dx.doi.org/10.1002/jmor.10598

Ramcharitar J., Gannon D.P., Popper A.N. 2006. Bioacoustics of the family Sciaenidae (croakers and drumfishes). Trans. Amer. Fish. Soc. 135: 1409-1431. http://dx.doi.org/10.1577/T05-207.1

Reichenbacher B. Sienknecht U., Küchenhoff H., et al. 2007. Combined otolith morphology and morphometry for assessing taxonomy and diversity in fossil and extant killifish (Aphanius, $\dagger$ Prolebias). J. Morph. 268: 898-915. http://dx.doi.org/10.1002/jmor.10561

Robinson B.W., Wilson D.S. 1994. Character release and displacement in fishes: a neglected literature. Amer. Naturalist 144: 596-627.

http://dx.doi.org/10.1086/285696

Sadighzadeh S., Tuset V.M., Valinassab T., et al. 2012. Comparison of different otolith shape descriptors and morphometrics in the identification of closely related species of Lutjanus spp. from the Persian Gulf. Mar. Biol. Res. 8: 802-814. http://dx.doi.org/10.1080/17451000.2012.692163

Schulz-Mirbach T., Heß M., Plath M. 2011. Inner ear morphology in the Atlantic Molly Poecilia mexicana - First detailed microanatomical study of the inner ear of a Cyprinodontiform species. PLoS One 6(11): e27734. http://dx.doi.org/10.1371/journal.pone.0027734

Sisneros J.A., Bass A.H. 2003. Seasonal plasticity of peripheral au- ditory frequency sensitivity. J. Neurosci. 23: 1049-1058.

Teimori A., Jawad L.A.J., Al-Kharusi L.H., et al. 2012. Late Pleistocene to Holocene diversification and historical zoogeography of the Arabian killifish (Aphanius dispar) inferred from otolith morphology. Sci. Mar. 76(4): 637-645. http://dx.doi.org/10.3989/scimar.03635.26C

Thayer G.W., Chester A.J. 1989. Distribution and abundance of fishes among basin and channel habitats in Florida Bay. Bull. Mar. Sci. 44: 200-219.

Tuset V.M., Piretti S., Lombarte A., et al. 2010. Using sagittal otoliths and eye diameter for ecological characterization of deepsea fish: Aphanopus carbo and A. intermedius from NE Atlantic waters. Sci. Mar. 74: 807-814. http://dx.doi.org/10.3989/scimar.2010.74n4807

Valinassab T., Adjeer M., Momeni M. 2010. Biomass estimation of demersal fishes in the Persian Gulf and Oman Sea by swept area method. Iranian Fisheries Research Organization Press, 356 pp.

Volpedo A.V., Echeverría D.D. 2003. Ecomorphological patterns of the sagitta in fish on the continental shelf off Argentine. Fish. Res. 60: 551-560. http://dx.doi.org/10.1016/S0165-7836(02)00170-4

Wainwright P.C. 1996. Ecological explanation through functional morphology: the feeding biology of sunfishes. Ecology 77: 1336-1343. http://dx.doi.org/10.2307/2265531

Wainwright P.C., Bellwood D.R. 2002. Ecomorphology of feeding in coral reef fishes. In: Sale P.F. (ed.), Coral reef fishes: dynamics and diversity in a complex ecosystem. Academic Press, pp. $33-55$. http://dx.doi.org/10.1016/B978-012615185-5/50004-9

Wainwright P.C., Ferry-Graham L.A., Waltzek T.B., et al. 2001. Evaluating the use of ram and suction during prey capture by cichlid fishes. J. Exp. Biol. 204: 3039-3051.

Weissburg M.J. 2005. Sensory biology: linking the internal and external ecologies of marine organisms. Mar. Ecol. Prog. Ser. 287: 263-265. http://dx.doi.org/10.3354/meps287263

Winn H.E. 1967. Vocal facilitation and biological significance of toadfish sounds. In: Tavolga W.N (ed), Marine Bio-Acoustics II. Pergamon Press, pp. 283-303. 